\title{
Note
}

J. Jpn. Soc. Colour Mater. (SHIKIZAI), 72〔8],489-493(1999)

\section{Temporal Stability of Azo Second-order Nonlinear Optical Chromophores Linked with Perfluorocyclopentenyl Moiety}

\author{
Masaki Matsui*, Hiroshige Muramatsu*, Kazumasa Funabiki* Katsuyoshi Shibata*, \\ Kazuo Hirota ${ }^{* *}$, Masahiro Hosoda ${ }^{* *}$ and Kazuo Ta ${ }^{* *}$
}

\begin{abstract}
The temporal stability of azo second-order nonlinear optical chromophores linked with a perfluorocyclopentenyl moiety doped in polymers was examined. The retention of second-order nonlinear optical coefficient $\left(d_{33}\right)$ of 1,2-bis $[4-[4-[N-$ ethyl - $N-(2$ - hydroxyethyl)amino] phenylazo] phenylthio] perfluorocyclopentene doped in poly(methyl methacrylate) after $530 \mathrm{~h}$ at $50^{\circ} \mathrm{C}$ was $5 \%$. That of 1,2 -bis [4(2,4-diaminophenylazo)phenylthio]perfluorocyclopentene doped in poly(methyl methacrylate-co-methacrylic acid) was improved to $45 \%$ by the amido formation between azo dye and polymer matrix.
\end{abstract}

Key-words: Azo dye, Temporal stability, Second-order nonlinear optical coefficient $\left(d_{33}\right)$, Functional dye, Perfuorocycloalkenyl

\section{Introduction}

Second-order nonlinear optical chromophores (NLOphores) are required to have high nonlinearity and excellent temporal stability $^{1,2)}$. In our previous paper, 1,2-bis[4[4-[N-ethyl - N-(2-hydroxyethyl)amino ]phenylazo ] phenylthio ] perfluorocyclopentene (3b), being more hypsochromic $\left(\lambda_{\max }=448 \mathrm{~nm}\right.$ $(\varepsilon=57500)$ in THF) than 4-nitrophenylazo- $N$ ethyl-N-(2-hydroxyethyl)aniline (DR $1, \lambda_{\max }$ $=488 \mathrm{~nm}(\varepsilon=31000))$, has been reported to show higher second-order nonlinearity, due to its more intense molar absorption coefficient ${ }^{3}$.

Received March 19, 1999

* Department of Chemistry, Faculty of Engineering, Gifu University, Yanagido, Gifu 5011193, Japan

** Research and Development Center, Unitika Ltd., Kozakura 23, Uji, Kyoto 611-0021, Japan
However, the temporal stability of $\mathbf{3 b}$ doped in poly(methyl methacrylate) (PMMA) after 530 $\mathrm{h}$ at $50^{\circ} \mathrm{C}$ was much lower (5\% retention) than that of DR $1(20 \%)$. Therefore, we have tried to improve the temporal stability of azo NLOphore linked with perfluorocyclopentenyl moiety. Generally, the orientation of doped NLOphores can be stabilized in polymers having high transition temperature $(T g)^{4}$. In our work, the temporal stability of $3 \mathbf{b}$ after $530 \mathrm{~h}$ at $50^{\circ} \mathrm{C}$ was in the order of doped polymers : poly(methyl methacrylate-co-methacrylic acid) (poly(MMA-co-MAA), $T g=105^{\circ} \mathrm{C}, 10 \%$ retention) $>$ polycarbonate $\left(\mathrm{PC}, 150^{\circ} \mathrm{C}, 7\right.$ $\%)>$ PMMA $\left(105^{\circ} \mathrm{C}, 5 \%\right)$. This result suggested that not only high $\mathrm{Tg}$ polymers but also polymers which form the covalent bonds with NLOphores could depress the relaxation behavior of oriented NLOphores. Therefore, the improvement of temporal stability of 1,2- 
bis [(arylazo)phenylthio] perfluorocyclopentenes doped in poly(MMA-co-MAA) has been examined in this report.

\section{Experimental}

\subsection{Instruments}

Melting points were measured by a Yanagimoto MP-S2 micro-melting-point apparatus. NMR spectra were taken on a JEOL $\alpha-400$ spectrometer. Mass spectra were measured with Shimadzu QP-1000 and 9020-DF spectrometers. UV spectra were taken on Shimadzu UV-160A and Hitachi U4000 spectrometers. Thermal analysis was performed with a Perkin-Elmer DSC-7 instrument. The refractive index was determined by a Mizojiri Kogaku DVA-36VWLD ellipsometer. The film thickness was measured by Dektak 3030 surface profile measuring system.

\subsection{Materials}

1,2 - Bis(4 - aminophenylthio)perfluorocyclopentene (1) and 1,2-bis [4-[4-[N-ethyl-N-(2hydroxyethyl)amino ] phenylazo ] phenylthio ] perfluorocyclopentene $(\mathbf{3 b})$ were prepared as described in our previous paper ${ }^{3)}$. DR 1, 1naphthylamine, $m$-phenylenediamine, and poly(MMA-co-MAA) $\left(60: 40, \quad T g=105^{\circ} \mathrm{C}\right.$, $\mathrm{Mw}=34000$ ) were purchased from Tokyo Kasei Co., Ltd.

\subsection{Synthesis of 1,2-Bis[4-(arylazo)phenyl- \\ thio]perfluorocyclopentene (3)}

To an acetic acid-propionic acid $(5: 1)$ mixed solution $(10 \mathrm{ml})$ of $1,2-\mathrm{bis}\left(4-\mathrm{amino}^{-}\right.$ phenylthio)perfluorocyclopentene $1(5.0 \mathrm{mmol})$ was added conc. hydrochloric acid $(4.0 \mathrm{ml}, 45$ $\mathrm{mmol})$. The mixture was stirred for $30 \mathrm{~min}$ at room temperature. After the reaction was completed, the mixture was cooled to $0^{\circ} \mathrm{C}$. To the mixture was added an aqueous solution (10 $\mathrm{ml})$ of sodium nitrite $(3.3 \mathrm{~g}, 20 \mathrm{mmol})$ and the mixture was stirred for $1 \mathrm{~h}$ at $0^{\circ} \mathrm{C}$. To the mixture was added an acetic acid-propionic acid (5: 1) mixed solution (10 $\mathrm{ml})$ of arylamines $2(20 \mathrm{mmol})$ and the mixture was stirred for $1 \mathrm{~h}$. The $\mathrm{pH}$ value of the solution was adjusted at 7.0 with an aqueous sodium hydroxide solution. The resulting precipitate was filtered and purified by column chromatography ( $\mathrm{SiO}_{2}, \mathrm{CH}_{3} \mathrm{COOC}_{2} \mathrm{H}_{5}: \mathrm{C}_{6} \mathrm{H}_{12}=1: 1$ ). Physical and spectral data of 3 are shown below.

1,2-Bis [ 4 - [ 4-(diethylamino)phenylazo ]phenylthio] perfluorocyclopentene (3a).

Yield $28 \%$; mp $164-165^{\circ} \mathrm{C} ;{ }^{1} \mathrm{H}$ NMR $\left(\mathrm{CDCl}_{3}\right)$ $\delta=1.22(\mathrm{t}, J=7.2 \mathrm{~Hz}, 12 \mathrm{H}), 3.45(\mathrm{q}, J=7.2$ $\mathrm{Hz}, 8 \mathrm{H}), 6.71(\mathrm{~d}, J=9.2 \mathrm{~Hz}, 4 \mathrm{H}), 7.55(\mathrm{~d}, J=$ $8.7 \mathrm{~Hz}, 4 \mathrm{H}), 7.80(\mathrm{~d}, J=8.7 \mathrm{~Hz}, 4 \mathrm{H}), 7.82(\mathrm{~d}, J=$ $9.2 \mathrm{~Hz}, 4 \mathrm{H}) ;{ }^{19} \mathrm{~F} \mathrm{NMR}\left(\mathrm{CDCl}_{3}\right.$, ext. $\left.\mathrm{CF}_{3} \mathrm{COOH}\right)$ $\delta=-52.59(2 \mathrm{~F}),-29.62(4 \mathrm{~F}) ; \operatorname{EIMS}(70 \mathrm{eV}) \mathrm{m} / z$ (rel. intensity) $742\left(\mathrm{M}^{+}\right.$; 26), 148 (100). Found: C, $59.50 ; \mathrm{H}, 4.58 ; \mathrm{N}, 10.87 \%$. Calcd for $\mathrm{C}_{37} \mathrm{H}_{36}$ $\mathrm{F}_{6} \mathrm{~N}_{6} \mathrm{~S}_{2}: \mathrm{C}, 59.83 ; \mathrm{H}, 4.88 ; \mathrm{N}, 11.31 \%$.

1,2-Bis [4-[4-[bis(2-hydroxyethyl)amino $]$ phenylazo] phenylthio] perfluorocyclopentene (3c).

Yield $28 \%$; mp 121-124 ${ }^{\circ} \mathrm{C} ;{ }^{1} \mathrm{H}$ NMR $\left(\mathrm{CDCl}_{3}\right)$ $\delta=2.96$ (br s, 4H), 3.73-3.77 (m, 8H), 3.95-3.96 $(\mathrm{m}, 8 \mathrm{H}), 6.97(\mathrm{~d}, J=7.2 \mathrm{~Hz}, 4 \mathrm{H}), 7.56(\mathrm{~d}, J=$ $8.7 \mathrm{~Hz}, 4 \mathrm{H}), 7.82(\mathrm{~d}, J=8.7 \mathrm{~Hz}, 4 \mathrm{H}), 7.86(\mathrm{~d}, J=$ $7.2 \mathrm{~Hz}, 4 \mathrm{H}) ;{ }^{19} \mathrm{~F} \mathrm{NMR}\left(\mathrm{CDCl}_{3}\right.$, ext. $\left.\mathrm{CF}_{3} \mathrm{COOH}\right)$ $\delta=-51.93(2 \mathrm{~F}),-28.91(4 \mathrm{~F})$; EIMS $(70 \mathrm{eV})$ $m / z$ (rel. intensity) $806\left(\mathrm{M}^{+} ; 2\right), 582$ (100). Found: C, 55.18; H, 4.51; N, $9.93 \%$. Calcd for $\mathrm{C}_{37} \mathrm{H}_{36} \mathrm{~F}_{6} \mathrm{~N}_{6} \mathrm{O}_{4} \mathrm{~S}_{2}$ : C, $55.08 ; \mathrm{H}, 4.50 ; \mathrm{N}$, $10.42 \%$.

1,2-Bis [4-(4-aminonaphthylazo)phenylthio ] perfluorocyclopentene (3d).

Yield $31 \%$; mp $222-223^{\circ} \mathrm{C} ;{ }^{1} \mathrm{H}$ NMR $\left(\mathrm{CDCl}_{3}\right)$ $\delta=6.81(\mathrm{~d}, J=8.8 \mathrm{~Hz}, 2 \mathrm{H}), 7.03(\mathrm{br} \mathrm{s}, 4 \mathrm{H})$, $7.49(\mathrm{t}, J=8.3 \mathrm{~Hz}, 2 \mathrm{H}), 7.62(\mathrm{t}, J=8.3 \mathrm{~Hz}, 2 \mathrm{H})$, $7.69(\mathrm{~d}, J=8.5 \mathrm{~Hz}, 4 \mathrm{H}), 7.94(\mathrm{~d}, J=8.5 \mathrm{~Hz}$, $4 \mathrm{H}), 7.98(\mathrm{~d}, J=8.8 \mathrm{~Hz}, 2 \mathrm{H}), 8.21(\mathrm{~d}, J=8.3$ $\mathrm{Hz}, 2 \mathrm{H}), 8.93(\mathrm{~d}, J=8.3 \mathrm{~Hz}, 2 \mathrm{H}) ;{ }^{19} \mathrm{~F}$ NMR $\left(\mathrm{CDCl}_{3}\right.$, ext. $\left.\mathrm{CF}_{3} \mathrm{COOH}\right) \delta=-52.18 \quad(2 \mathrm{~F})$, $-29.14(4 \mathrm{~F})$; EIMS $(70 \mathrm{eV}) \mathrm{m} / z$ (rel. intensity) 
$730\left(\mathrm{M}^{+}\right.$; 2), 142 (100). Found: C, 60.79; H, $3.47 ; \mathrm{N}, 11.29 \%$. Calcd for $\mathrm{C}_{37} \mathrm{H}_{24} \mathrm{~F}_{6} \mathrm{~N}_{6} \mathrm{~S}_{2}: \mathrm{C}$, $60.82 ; \mathrm{H}, 3.31 ; \mathrm{N}, 11.50 \%$.

\section{1,2-Bis [4-(2,4-diaminophenylazo)phenylthio ] -} perfluorocyclopentene (3e).

Yield $36 \%$; mp 205-206 $6^{\circ}$; ${ }^{1} \mathrm{H}$ NMR $\left(\mathrm{CDCl}_{3}\right)$ $\delta=5.84(\mathrm{~d}, J=2.2 \mathrm{~Hz}, 2 \mathrm{H}), 6.02(\mathrm{dd}, J=8.2$ and $2.2 \mathrm{~Hz}, 2 \mathrm{H}$ ), 6.07 (br s, 4H), $7.22(\mathrm{br} \mathrm{s}, 4 \mathrm{H}$ ), $7.35(\mathrm{~d}, J=8.2 \mathrm{~Hz}, 2 \mathrm{H}), 7.58(\mathrm{~d}, J=8.4 \mathrm{~Hz}$, $4 \mathrm{H}), \quad 7.71(\mathrm{~d}, \quad J=8.4 \mathrm{~Hz}, 4 \mathrm{H}) ;{ }^{19} \mathrm{~F} \quad \mathrm{NMR}$ $\left(\mathrm{CDCl}_{3}\right.$, ext. $\left.\mathrm{CF}_{3} \mathrm{COOH}\right) \delta=-52.58 \quad(2 \mathrm{~F})$, $-29.61(4 \mathrm{~F})$; EIMS $(70 \mathrm{eV}) \mathrm{m} / z$ (rel. intensity) $660\left(\mathrm{M}^{+} ; 7\right), 107$ (100). Found: C, 53.22; H, $3.55 ; \mathrm{N}, 17.09 \%$. Calcd for $\mathrm{C}_{29} \mathrm{H}_{22} \mathrm{~F}_{6} \mathrm{~N}_{8} \mathrm{~S}_{2}$ : C, 52.72 ; H, 3.36 ; N, $16.96 \%$.

\subsection{Film Preparation}

NLOphores $3 \mathbf{a}-\mathbf{e}(2.0 \mathrm{~mol} \%)$ were dissolved in a chloroform solution of the polymer matrix. The mixture was filtered $(0.5 \mu \mathrm{m})$, put on an ITO glass plate, and spin-coated (1000 rpm, $20 \mathrm{sec})$. The film was dried in vacuo for $3 \mathrm{~h}$.

\subsection{Corona-Poling}

The film was heated to $\mathrm{Tg}\left(105^{\circ} \mathrm{C}\right)$ of poly(MMA-co-MAA) and corona-poled $(7 \mathrm{kV}$ $\mathrm{cm}^{-1}, 2 \mathrm{~min}$ or $30 \mathrm{~min}$ ). After cooling the film, the applied high voltage was removed.

\subsection{Second Harmonic Generation (SHG) \\ Measurement}

The SHG of film was measured by the Maker fringe method using a $\mathrm{Q}^{-}$-switched $\mathrm{Nd}$ :
YAG laser $(\lambda=1064 \mathrm{~nm})$. A $1 \mathrm{~mm}$-thick $\mathrm{y}^{-}$ cut quartz plate $\left(d_{11}=0.33 \mathrm{pm} \mathrm{V}^{-1}\right)$ was used as the reference. The $d_{33}$ value was determined by the mean square methods using the relationship between the second harmonic light intensity and the incident angle of the coronapoled film as described in our previous paper ${ }^{3)}$.

\section{Results and Discussion}

Scheme 1 shows the synthesis of NLOphores 3a-e. Bis(arylamino) intermediate $\mathbf{1}$ was obtained by the reaction of $1,2-$ dichloroperfluoro-1-cyclopentene with 4aminothiophenol in the presence of sodium hydride. Then, the intermediate 1 was diazotized and coupled with arylamines $2 \mathbf{a}-\mathbf{e}$ to afford the NLOphores $3 \mathbf{a}-\mathbf{e}$ in moderate yields.

The properties of NLOphores are given in Table 1. The absorption maxima of NLO-
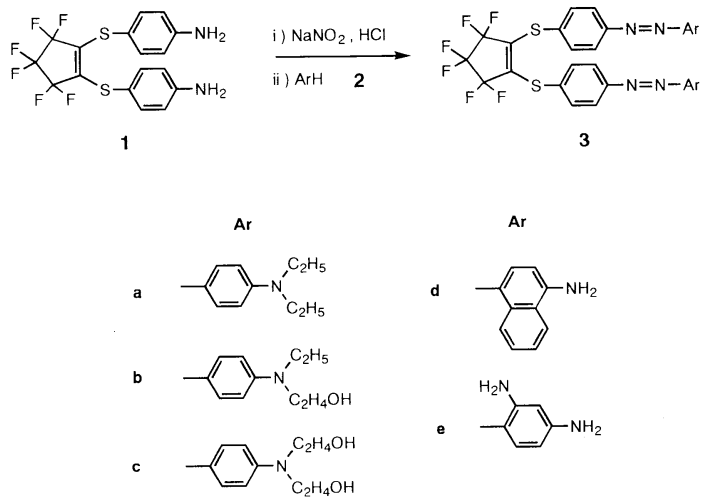

Scheme 1

Table 1 Properties of NLOphores $\mathbf{3 a - e}$ and films.

\begin{tabular}{|c|c|c|c|c|c|c|}
\hline \multirow{2}{*}{ NLOphore } & \multirow{2}{*}{$\frac{\lambda_{\max }(\varepsilon)^{\mathrm{a}}}{\mathrm{nm}}$} & \multirow{2}{*}{$\frac{T d^{b}}{{ }^{\circ} \mathrm{C}}$} & \multirow{2}{*}{$\frac{\text { film thickness }}{\mu \mathrm{m}}$} & \multicolumn{2}{|c|}{ refractive index } & \multirow{2}{*}{$\frac{d_{33}{ }^{\mathrm{c}}}{\mathrm{pm} \mathrm{V}^{-1}}$} \\
\hline & & & & $532 \mathrm{~nm}$ & $1064 \mathrm{~nm}$ & \\
\hline $3 \mathbf{a}$ & $444(59400)$ & 290 & 0.55 & 1.54 & 1.50 & 7.3 \\
\hline $3 \mathbf{b}$ & $448(57500)$ & 290 & 2.68 & 1.54 & 1.50 & 7.8 \\
\hline $3 c$ & $445(60700)$ & 277 & 1.78 & 1.54 & 1.50 & 10 \\
\hline $3 d$ & $475(64700)$ & 284 & 0.73 & 1.54 & 1.50 & 15 \\
\hline $3 e$ & $460(56700)$ & 269 & 0.60 & 1.54 & 1.50 & $12^{\mathrm{d}}$ \\
\hline
\end{tabular}

${ }^{\text {a }}$ Measured in THF. ${ }^{\mathrm{b}} \mathrm{TG}-\mathrm{DTA}$ analysis $\left(10^{\circ} \mathrm{C} \mathrm{min}^{-1}\right.$, under air).

${ }^{\mathrm{c} N L O p h o r e: ~} 2.0 \mathrm{~mol} \%$, corona poling : $7 \mathrm{kV} \mathrm{cm}^{-1}, 105^{\circ} \mathrm{C}, 2 \mathrm{~min}$.

${ }^{\mathrm{d}}$ Under the condition of $7 \mathrm{kV} \mathrm{cm} \mathrm{cm}^{-1}, 105^{\circ} \mathrm{C}$, and $30 \mathrm{~min}$ for corona-poling: $d_{33}=8.0 \mathrm{pm} \mathrm{V}^{-1}$. Under the condition of $7 \mathrm{kV} \mathrm{cm}^{-1}, 105^{\circ} \mathrm{C}, 30 \mathrm{~min}$, in the presence of DCC (1 eq for $\left.3 \mathrm{e}\right)$ for corona-poling: $d_{33}=7.9 \mathrm{pm} \mathrm{V}^{-1}$. 
phores $3 \mathbf{a}-\mathbf{e}$ were observed at around $444-$ $475 \mathrm{~nm}$ in THF. The molar absorption coefficients were $56700-64700$, being much larger than that of DR $1\left(\lambda_{\max }=488 \mathrm{~nm}\right.$, $\varepsilon=31000$ in THF). The decomposition temperatures ( $T d$ 's) of NLOphores $3 \mathbf{a}-\mathbf{e}$ measured by TG-DTA analysis were observed at around $269-290^{\circ} \mathrm{C}$, indicating that the NLOphores were sufficiently stable under the heating and corona poling conditions. The $d_{33}$ values of the films were measured to be around $10 \mathrm{pm} \mathrm{V}^{-1}$.

The temporal stability of NLOphores $3 \mathbf{a}-\mathbf{e}$ doped in poly(MMA-co-MAA) is shown in Figure 1. The stability was in the order of NLOphores: 3e $>$ 3b, 3c, 3d $>>$ 3a. The temporal stability of hydroxy- and aminofree- $\mathbf{3 a}$ was very low.

Next, the temporal stability of amino derivative $3 \mathbf{e}$ corona-poled under different conditions is indicated in Figure 2. It is clear that NLOphore $3 \mathbf{e}$ corona-poled for $30 \mathrm{~min}$ in the presence of $N, N^{\prime}$-dicyclohexylcarbodiimide (DCC), a catalyst for amido formation, was most stable.

These results indicated that the formation of amido linkage between the amino groups in $\mathbf{3 e}$



Fig. 1 Temporal stability of NLOphores $3 \mathbf{a}-\mathbf{e}$ doped in poly(MMA-co-MAA)

NLOphores 3a-e (2.0 mol\%) were corona-poled at $7 \mathrm{kV} \mathrm{cm}{ }^{-1}$ for $2 \mathrm{~min}$ at $105^{\circ} \mathrm{C}$. The films were kept at $50^{\circ} \mathrm{C}$. The change in relative $d_{33}$ value with relaxation time is indicated. and carboxy group in poly(MMA-co-MAA) could depress relaxation of the oriented NLOphore.

In conclusion, the temporal stability of azo NLOphores linked with a perfluorocyclopentenyl moiety was improved. The retention of $d_{33}$ value was improved from $5 \%$ for 1,2-bis [4-[4-[N-ethyl- $N$-(2-hydroxyethyl)amino ] phenylazo ] phenylthio ] perfluorocyclopentene doped in PMMA to $45 \%$ for 1,2 -bis [4(2,4 - diaminophenylazo)phenylthio ]perfluorocyclopentene doped in poly(MMA- ${ }^{-}{ }^{-}$ MAA) by the amido formation between the azo NLOphore and polymer matrix.

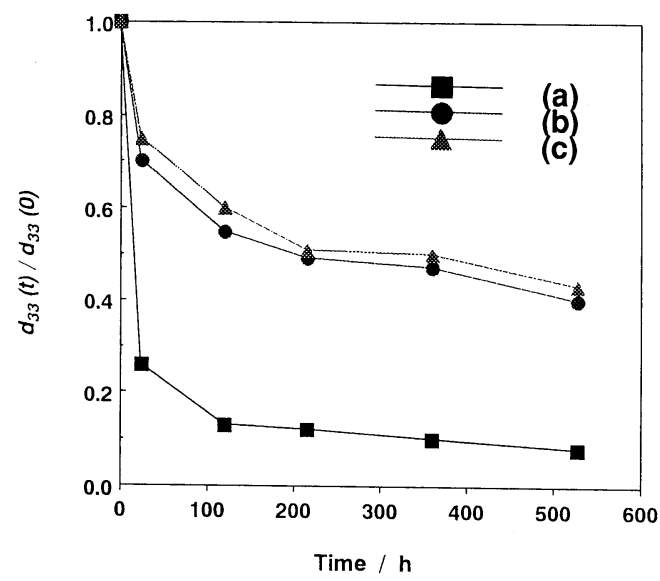

Fig. 2 Temporal stability of NLOphores $3 \mathbf{e}$ doped in poly(MMA-co-MAA)

NLOphore $3 \mathbf{e}$ was corona-poled at $7 \mathrm{kV} \mathrm{cm}^{-1}$ (a) for $2 \mathrm{~min}$, (b) $30 \mathrm{~min}$ (in the absence of DCC), and (c) $30 \mathrm{~min}$ (in the presence of DCC), respectively. The films were kept at $50^{\circ} \mathrm{C}$. The change in relative $d_{33}$ value with relaxation time is indicated.

\section{References}

1) T. J. Marks and M. A. Ratner: Angew. Chem. Int. Ed. Engl., 34, 155 (1995).

2) D. M. Burland, R. D. Miller, and C. A. Walsh : Chem. Rev., 94, 31 (1994).

3) M. Matsui, M. Tsuge, K. Funabiki, K. Shibata, H. Muramatsu, K. Hirota, M. Hosoda, K. Tai, H. Shiozaki, M. Kim, and K. Nakatsu: J. Fluorine Chem., in press.

4) D. Yu and L. Yu: Macromolecules, 27, 6718 (1994). 
JJSCM, 72〔8〕 (1999)

ペルフルオロシクロペンテニル部位で結合した アゾ系の二次非線形光学クロモファーの配向緩和

\section{松居正樹*・船曳一正夫*・村松広重*・柴田勝喜* •}

広田一雄 ${ }^{* *} \cdot$ 細田雅弘 ${ }^{* *} \cdot$ 田井和夫**

*岐皁大学工学部応用精密化学科 岐阜県岐阜市柳戸 1-1（可501-1193）



\section{要旨}

ポリマーにドープしたアゾ系の二次の線形光学クロモファーの配向緩和を検討した。PMMA 中にドープされ た 1,2-ビス[4-[4-[N-エチル-N-(2-ヒドロキシエチル)アミノ]フェニルアゾ]フェニルチオ]ペルフルオロシク ロペンテンの 530 時間後, $50^{\circ} \mathrm{C}$ での二次の非線形光学定数 $\left(d_{33}\right)$ は， $5 \%$ 保持されていた。メチルメタクリ

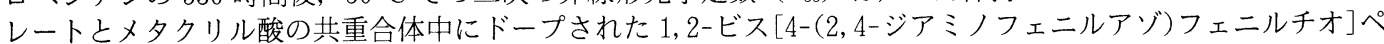
ルフルオロシクロペンテンの配向緩和は, アゾ色素とポリマーマトリックス間のアミド結合の形成のために, $d_{33}$ 值は $45 \%$ 保持まで改善された。 